\title{
MONETARY AND FISCAL POLICY ANALYSIS: WHICH IS MORE EFFECTIVE?
}

\author{
Muhamad Yunanto ${ }^{1}$ \& Henny Medyawati ${ }^{2}$ \\ Faculty of Economics, Gunadarma University \\ ('1myunanto@staff.gunadarma.ac.id, ${ }^{2}$ henmedya@staff.gunadarma.ac.id)
}

\begin{abstract}
Fiscal policy is an adjustment in the income and expenditure of government as stipulated in the state budget in order to achieve better economic stability and pace of development. The main objective of this study was to measure and analyze Fiscal and Monetary Policy of the Gross Domestic Product (GDP). Fiscal Policy Multiplier (FPM) and Monetary Policy Multiplier (MPM) are used to answer the debate where more effective between fiscal policy and monetary policy. Short-term models derived through error correction model (ECM), which also forms the derivative equation. A system of simultaneous equations two stage least squares (TSLS), is used to describe the sensitivity analysis (response) of shocks to the policy change of important macroeconomic indicators. The results showed that during the study period, Indonesia's monetary policy more effective than fiscal policy.
\end{abstract}

Keywords: monetary policy, fiscal policy, Mundell-Flemming Model

\section{INTRODUCTION}

Indonesia may be mentioned as a country characterized by an open economy is small so that the macroeconomic fluctuations in response to the global economy. A small open economy is the economy assuming the mobility of capital (capital flow in/out) is perfect. The shake-up due to changes in world prices of crude oil as a representation of the world inflation rate and interest rates significantly have implications for the world of domestic variables. It shows a small open economy as Indonesia is highly vulnerable to shaking world variables (Arif et al., 2006).

Developments in the financial sector are quite rapidly if there can be offset by the developments in the real sector, in turn causing structural imbalances in the economy (Solikin, 2005). On the conditions of the under-economy capacity, the expansionary fiscal and monetary policy effectively affect real output. Simorangkir (2007) describes the optimal monetary policy response will be influenced by multiple scenarios in a deep on fiscal policy. The impact of monetary and fiscal policy interactions on social welfare will be positive when fiscal policy is exogenous. In the financial/economic crisis conditions, the combination of policies of fiscal expansion and monetary expansion are very effective to encourage economic growth (Simorangkir \& Adamanti, 2010).

Konuki (2000) analyzes the impact of shortterm fiscal and monetary policies to aggregate demand by using the IS-LM model-BOP with structural analysis method of ECM. In Indonesia, Siregar and Ward (2000) by using the methodology of Stuctural Vector Auto Regressive (SVAR) indicates that the transmission mechanism of monetary policy can be evaluated from the analysis of the impulse response. This research suggests that the macro-economic fluctuations to stabilize Indonesia, Both fiscal and monetary policies that have to work together. Research results by Rahutami (2007) show that fiscal and monetary policy is causality, that fiscal and monetary coordination was important because interest rates and money are the two primary variables that should get more attention from Bank Indonesia because it interacts strongly with the Government budget. Maryatmo (2004) States that reciprocal relationship exists between the fiscal and monetary variables as 
well as the relationship of reciprocity between the fiscal and monetary instruments mutually eliminate (substitution). Mochtar (2004), states that in maintaining price stability, the Monetary Authority requires a high commitment of the fiscal authority to discipline and fiscal sustainability. Failure to resolve the problem of fiscal performance optimally may decrease the effectiveness of monetary policy in controlling inflation in the inflation targeting framework.

Studies conducted by Giavazzi and Pagano (1990) and research by Hemming et.al (2002) also found that fiscal expansion have negative multiplier effects for the economy. Ganev et al. (2002) studied the effects of monetary shocks in the ten Central and Eastern European countries (CEE) and found no evidence to suggest that changes in interest rates can affect the output. Ortiz et.al (2002) make modifications to the model of the Mundell-Fleming, namely by introducing fiscal deficit implications and international reserves as a determinant for the country risk rate. Leitimo (2004) stresses in case of conflicts regarding the size of the output gap, monetary and fiscal policy will result in the volatility of interest rates and exchange rates are significant as a result of the conflict the gap in output. Perotti (2005) found a much smaller multiplier for the countries of Europe. Blanchard and Perotti (2002) and the Romer (2008) found that fiscal stimulus of 1 per cent of GDP impact on increasing the GDP of almost 1 percent and as much as 2 to 3 percent of GDP while the peak effect occurs, a few years later. In the meantime, cross-country studies conducted by Christiansen (2008) found the fiscal multiplier is small for the economy and in some cases were found to be negative by a multiplier. Freedman et al. (2009) show that fiscal policy expansion around the world combined with monetary policy accommodating can have a significant multiplier effect on the world economy. There are three questions that are most commonly identified in the literature, namely the question of liquidity, the question of price and exchange rate question (Chuku, 2009). Hsieh (2009) analyze the parity purchasing power parity model, interest rate parity (the uncovered interest parity models,) the monetary model and Mundell-Flemming Model extended to the exchange rate IDR/USD. The results showed that an increase in interest rates or inflation will cause depreciation of the rupiah. Simorangkir et al. (2010) show that fiscal and monetary policy effectively affect real output. Santoso (2012) stated that most of the fiscal and monetary policy mix in Indonesia from 19842010 is monetary policy tight-fiscal tight (complement) and monetary policy tight- fiscal loose (substitution). Economy will usually get better when fiscal and monetary authorities to coordinate both the policy. The crisis has made it clear that in addition to achieving a stable output gap and inflation stable, policy makers should also pay attention to a lot of targets, including the composition of output, asset price behaviour and the leverage of the different agencies. It is also clear that there are many more instruments, which is a combination of traditional monetary policy and fiscal policy (Blanchard et.al., 2010). In his latest study, Blanchard et.al (2013) stated that the relative role of monetary policy, fiscal policy, and policy macroprudential still growing.

This study is a continuation of previous research (Yunanto et al., 2013) which analyzed the macroeconomic changes structurally i.e. analyzing balance short-term economic models and long-term strategy in preference to fiscal and monetary policy, with the final target is the output (GDP). In the study there is no reduced form to explain the structural equations, not yet analyzed the level of effectiveness between monetary policy and fiscal policy in Indonesia and there has been no sensitivity analysis of fiscal policy and monetary policy. The purpose of this research is to analyze the effectiveness of monetary and fiscal policy affect the link between the operational target variable and specify the combination (mix of) monetary and fiscal policies better, associated with a sensitivity policy affect the economy in accordance with the basic characteristics of the economy of Indonesia. The contribution of this research is to contribute empirically over the findings in the development of the model, as well as the contribution of economic policy recommendations on the economy good normal conditions or crisis. 


\section{RESEARCH METHODS}

Types of data used in this research is time series data, quarterly data in the period 1990:1 up to 2011:4, based on a constant value (base year) in 2005, except for the data in the form of index value and percentage. The data comes from the economic and Financial Statistics (SEKI) is published by Bank Indonesia, the Central Bureau of statistics (BPS). Other data obtained from the Organisation for Economic Co-operation and Development (OECD). Variable for the real sector categorized in the monetary sector, the expenditure approach, the Government's financial sector and the external sector. Government spending, which is shopping for goods and services (Government consumption) as a proxy for fiscal policy, while monetary policy is measured by interest rates. Fiscal policy is assumed to be more emphasis on economic growth while monetary policy is more emphasized at a low inflation rate.

The development model used with some modifications to take into account the characte- ristics of Indonesia's economy and the behavior of the underlying economic variables. The model is composed of 11 of short term structural equations, structural equations are derived based on the assumption that the economy is represented by the homogeneous economic actors (Yunanto et al., 2013). This research is part of a research dissertation Yunanto (2013). Aggregate supply model used in the study of model calculations performed by Joseph et al. (1999) which is the development of an open economy macro models by Yoshino (1998). In his model, Yoshino used the inflation as measured by the survey of living costs (cost of living index) as factors that affect aggregate supply with positive relationships. The higher inflation (price level) then there is an incentive for manufacturers to increase production so as to increase aggregate supply.

Dynamic simultaneous equations in this research is overidentified. Overidentified equation solved by TSLS.

Table 1. The Classification Variable in the Equation

\begin{tabular}{|c|c|}
\hline Type of Variable & Description \\
\hline $\begin{array}{l}\text { Endogeneous Variable } \\
\text { 1. } \operatorname{KONS}(C) \\
\text { 2. } \operatorname{INV~}(I) \\
\text { 3. } \operatorname{KONP}(G) \\
\text { 4. } \operatorname{EKSP}(X) \\
\text { 5. } \operatorname{IMPR}(M) \\
\text { 6. } \operatorname{M} 2 \\
\text { 7. } \operatorname{KURS}(r) \\
\text { 8. } \operatorname{IHK}(P) \\
\text { 9. } \operatorname{KBLN}(F) \\
\text { 10. } \operatorname{PDBE}(Y) \\
\text { 11. } \operatorname{LK}(L)\end{array}$ & $\begin{array}{l}\text { Private Consumption } \\
\text { Investment } \\
\text { Government Consumption } \\
\text { Export } \\
\text { Import } \\
\text { Demand, Supply of Money } \\
\text { Exchange Rate } \\
\text { Consumer Price Index } \\
\text { Net Foreign Wealth } \\
\text { Gross Domestic Product Expenditure } \\
\text { Employment }\end{array}$ \\
\hline $\begin{aligned} & \text { Predetermined Variable } \\
& \text { 1. } \operatorname{PPJK}\left(T_{x}\right) \\
& \text { 2. } \operatorname{SUBS}\left(T_{r}\right) \\
& \text { 3. } \operatorname{BIRATE}(i) \\
& \text { 4. } \operatorname{IHEKS~}\left(\left(P_{x}\right)\right. \\
& \text { 5. } \text { IMPDN }\left(M_{-} W\right) \\
& \text { 6. } \text { IHIMP }\left(P_{m}^{*}\right) \\
& \text { 7. } \text { M1 } \\
& \text { 8. } \text { IHKD }\left(P^{*}\right) \\
& \text { 9. } \text { HMMD }(\text { Oil_W }) \\
& \text { 10. } \text { LIBOR }\left(i^{*}\right) \\
& \text { 11. } \varepsilon_{1 t^{-}} \varepsilon_{11 t}\end{aligned}$ & $\begin{array}{l}\text { Tax Income } \\
\text { Subsidy } \\
\text { Nominal Interest Rate } \\
\text { Export Commodity Price Index } \\
\text { Import Demand World } \\
\text { Import Commodity Price Index } \\
\text { Primary Money } \\
\text { World Commodity Price Index } \\
\text { World Crude Oil Prices } \\
\text { World Interest Rate (LIBOR) } \\
\text { A Lag periode of cointegration error }\end{array}$ \\
\hline
\end{tabular}




\section{RESULT AND DISCUSSION}

\section{Stationary Test Data and Cointegration}

Stasionary test data is carried out by the unit root tests Augmented Dickey-Fuller (ADF). Most of the data that have been tested, the data is not stationary at level and stationary on the process of difference data. The next stage of the test is Granger's cointegration test to see the relationship of all variables in the long run.

\section{Causality Test}

The interaction between fiscal and monetary policy is never one way direction or nature of causality. Following are the results of the optimal lag.
Table 3. Akaike Criteria

\begin{tabular}{clcc}
\hline No. & \multicolumn{1}{c}{ Variable } & Akaike & $\begin{array}{c}\text { Optimal } \\
\text { Lag }\end{array}$ \\
\hline 1. & Government & & \\
& Consumption & $-7.481054^{*}$ & 4 \\
2. & Money Supply & $-14.62122^{*}$ & 12 \\
3. & Exchange Rates & $-7.424746^{*}$ & 15 \\
\hline
\end{tabular}

In determining the optimal lag, there are several criteria, one of the criteria by using Akaike criteria (Gujarati, 2003). Regression that produces the smallest Akaike criterion is a regression model with the desired amount of lag. The value of F-stat and probability of causation test are presented in table 4 below.

Tabel 2. Result of Stationery Data Test

\begin{tabular}{|c|c|c|c|c|c|}
\hline \multirow{2}{*}{\multicolumn{2}{|c|}{ Variable/Unit Root Test }} & \multicolumn{3}{|c|}{ Critical Values Test: } & \multirow{2}{*}{$\begin{array}{l}\text { ADF-Test } \\
\text { Statistics }\end{array}$} \\
\hline & & $1 \%$ & $5 \%$ & $10 \%$ & \\
\hline $\begin{array}{l}\text { LOG(KONS) } \\
\text { D,LOG(KONS) }\end{array}$ & $\begin{array}{l}\text { Level } \\
\text { First Difference }\end{array}$ & -3.510 & -2.896 & -2.585 & $\begin{array}{l}2.848^{*} \\
-4.640 * * *\end{array}$ \\
\hline $\begin{array}{l}\text { LOG(INV) } \\
\text { D,LOG(INV) }\end{array}$ & $\begin{array}{l}\text { Level } \\
\text { First Difference }\end{array}$ & -3.507 & -2.895 & -2.584 & $\begin{array}{l}2.214 \\
-9.916^{* * *}\end{array}$ \\
\hline $\begin{array}{l}\text { LOG(KONP) } \\
\text { D,LOG(KONP) }\end{array}$ & $\begin{array}{l}\text { Level } \\
\text { First Difference }\end{array}$ & -3.511 & -2.896 & -2.585 & $\begin{array}{l}2.367 \\
-4.418 * * *\end{array}$ \\
\hline $\begin{array}{l}\text { LOG(EKSP) } \\
\text { D,LOG(EKSP) }\end{array}$ & $\begin{array}{l}\text { Level } \\
\text { First Difference }\end{array}$ & -3.507 & -2.895 & -2.584 & $\begin{array}{l}-1.175 \\
-6.904 * * *\end{array}$ \\
\hline $\begin{array}{l}\text { LOG(IMPR) } \\
\text { D,LOG(IMPR) }\end{array}$ & $\begin{array}{l}\text { Level } \\
\text { First Difference }\end{array}$ & -3.508 & -2.895 & -2.584 & $\begin{array}{l}-1.107 \\
-7.272 * * *\end{array}$ \\
\hline $\begin{array}{l}\mathrm{LOG}(\mathrm{M} 2) \\
\mathrm{D}, \mathrm{LOG}(\mathrm{M} 2)\end{array}$ & $\begin{array}{l}\text { Level } \\
\text { First Difference }\end{array}$ & -3.513 & -2.895 & -2.584 & $\begin{array}{l}0.444 \\
-9.434 * * *\end{array}$ \\
\hline $\begin{array}{l}\text { LOG(IHK) } \\
\text { D,LOG(IHK) }\end{array}$ & $\begin{array}{l}\text { Level } \\
\text { First Difference }\end{array}$ & -3.508 & -2.895 & -2.584 & $\begin{array}{l}1.179 \\
-6.106^{* * *}\end{array}$ \\
\hline $\begin{array}{l}\text { LOG(KURS) } \\
\text { D,LOG(KURS) }\end{array}$ & $\begin{array}{l}\text { Level } \\
\text { First Difference }\end{array}$ & -3.509 & -2.895 & -2.585 & $\begin{array}{l}-1.663 \\
-5.927 * * *\end{array}$ \\
\hline $\begin{array}{l}\text { LOG(KBLN) } \\
\text { D.LOG(KBLN) }\end{array}$ & $\begin{array}{l}\text { Level } \\
\text { First Difference }\end{array}$ & -3.507 & -2.895 & -2.584 & $\begin{array}{l}-1.061 \\
-11.39 * * *\end{array}$ \\
\hline $\begin{array}{l}\text { LOG(LK) } \\
\text { D,LOG(LK) } \\
\text { D,LOG(LK,2) }\end{array}$ & $\begin{array}{l}\text { Level } \\
\text { First Difference } \\
\text { Second Difference }\end{array}$ & -3.516 & -2.899 & -2.586 & $\begin{array}{l}1.570 \\
-1.800 \\
-5.318^{* * *}\end{array}$ \\
\hline LOG(PDBE) & Level & -3.513 & -2.897 & -2.586 & $3.173 * *$ \\
\hline Note : & $\begin{array}{l}\text { Stasionary at critic } \\
\text { Stasionary at critic } \\
\text { Stasionary at critic }\end{array}$ & $\begin{array}{l}\text { est } 1 \% \\
\text { est } 5 \% \\
\text { est } 10 \%\end{array}$ & & & \\
\hline
\end{tabular}


Table 4. Causality Test Between Government Consumption, Money Supply and Exchange Rate

\begin{tabular}{lccrl}
\hline No $\quad$ Causality & lag & Obs & F-Stat & \multicolumn{1}{c}{ Prob } \\
\hline 1. M2 $\leftarrow$ KONP & 1 & 90 & 4,37850 & $0,0393^{* *}$ \\
2. M $2 \leftarrow$ KURS & 12 & 79 & 5,51099 & 5, E-06*** \\
3. KONP $\leftarrow$ M2 & 13 & 78 & 2,08510 & $0,0316^{* *}$ \\
4. KONP $\leftarrow$ KURS & 4 & 87 & 3,71387 & $0,0081^{* *}$ \\
5. KURS $\leftarrow$ KONP & 4 & 87 & 0,57292 & 0,6831 \\
6. KURS $\leftarrow$ M2 & 12 & 79 & 1,13619 & 0,3519 \\
\hline
\end{tabular}

Table 4. indicates that a null hypothesis to causality test row, fiscal policy instruments, namely Government Consumption affects the Supply of money in a short period of time and does not affect the exchange rates (causality test number 1 and 5). Monetary policy instruments which affect the money supply and Government Consumption does not affect the exchange rates (causality test number 3 and 6). The money supply is affected by the exchange rate, the exchange rate affect the case Government Consumption. In this case the fiscal and monetary policy in the economy of Indonesia is the response from the turmoil of the global economy through a variable exchange rate, the prove that the economy of Indonesia meets the criteria as a small open economy. In line with research Rahutami (2007), the results of this research show that the interaction of monetary and fiscal policy is causality.

\section{Reduced Form}

Reduced form equation is an equation that describes the endogenous variables based only on predetermined variables and stochastic error. The result of the reduced form by the application EVIEWS_6 is as follows:

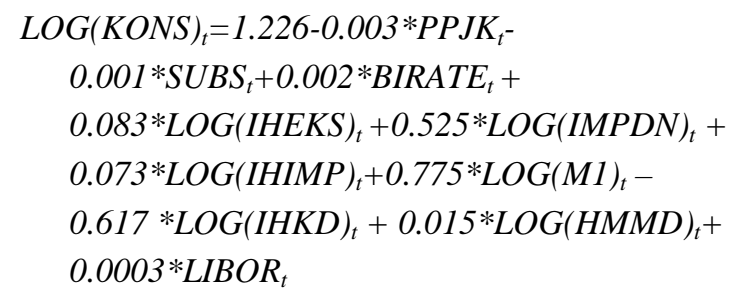

$L O G(I N V)_{t}=-0.0005-0.084 * P P J K_{t}-0.005 * S_{U B S}+$ $0.002 *$ BIRATE $_{t}-0.841 *$ LOG $(\text { IHEKS })_{t^{-}}$ $0.479 *$ LOG $(\text { IMPDN })_{t}+2.883 *$ LOG $(\text { IHIMP })_{t}+$

$$
\begin{aligned}
& 1.048 * \operatorname{LOG}(M 1)_{t}+0.022 * \operatorname{LOG}(I H K D)_{t}- \\
& 0.002 * \operatorname{LOG}(\mathrm{HMMD})_{t}+0.002 * \mathrm{LIBOR}_{t}
\end{aligned}
$$

$L O G(K O N P)_{t}=-0.057+0.047 * P^{2} J K_{t}-$ $0.005 * S^{2} B_{t}+0.003 * B^{2}$ RATE $_{t}-$ $0.796 *$ LOG $(\text { IHEKS })_{t}+0.132 *$ LOG $(\text { IMPDN })_{t}+$ $2.379 * \operatorname{LOG}(\text { IHIMP })_{t}+0.014 * \operatorname{LOG}(\mathrm{M} 1)_{t}+$ $0.007 * \operatorname{LOG}(\mathrm{IHKD})_{t}-0.379 * \operatorname{LOG}(\mathrm{HMMD})_{t^{-}}$ $0.720 *$ LIBOR $_{t}$

$L O G(E K S P)_{t}=3.858-0.005 * P P J K_{t}+0.010 * S_{U B S}+$ $0.014 *$ BIRATE $_{t}+1.358 *$ LOG $(\text { IHEKS })_{t}+$ $0.186 *$ LOG $(\text { IMPDN })_{t}+0.013 *$ LOG $(\text { IHIMP })_{t}+$ $0.673 * \operatorname{LOG}(\mathrm{M1})_{t}+0.222 * \operatorname{LOG}(\mathrm{IHKD})_{\mathrm{t}}-$ $0.123 * L O G(H M M D)_{t}-0.023 *{ }^{2} I B O R_{t}$

$L O G(I M P R)_{t}=-1.321-0.002 * P P J K_{t}+0.008 * S_{U B B S}+$ $0.011 *$ BIRATE $_{t}+1.206 *$ LOG $(\text { IHEKS })_{t}+$ $0.003 * \operatorname{LOG}(\text { IMPDN })_{t}+0.042 * \operatorname{LOG}(\text { IHIMP })_{t}+$ $0.693 * \operatorname{LOG}(\mathrm{M} 1)_{t}+0.0002 * \operatorname{LOG}(\text { IHKD })_{t}-$ $0.345 * \operatorname{LOG}(H M M D)_{t}-0.006 *{ }^{2} I B O R_{t}$

$L O G(M 2)_{t}=-4.527-0.008 * P P J K_{t}+0.002 *$ SUBS $_{t}+$ $0.004 *$ BIRATE $_{t}+0.009 *$ LOG $(\text { IHEKS })_{t}+$ $0.461 * L O G(I M P D N)_{t}+0.150 * L O G(\text { IHIMP })_{t}+$ $0.0007 *^{*} O G(M 1)_{t}+0.097 * \operatorname{LOG}(I H K D)_{t}-$ $0,096 * \operatorname{LOG}(H M M D)_{t}-0,026 * L^{2}{ }^{2} R_{t}$

$L O G(K U R S)_{t}=23.787-$

$0.012 * P P J K_{t}+0.056 * S_{U B S}+0.010 *$ BIRATE $_{t}+$ $0.631 *$ LOG $(\text { IHEKS })_{t}+0.011 *$ LOG $(\text { IMPDN })_{t}-$ $0.092 * \operatorname{LOG}(\text { IHIMP })_{t}+0.394 * \operatorname{LOG}(\mathrm{M} 1)_{t}-$ $10.060 * \operatorname{LOG}(\mathrm{IHKD})_{\mathrm{t}}+1.902 * \operatorname{LOG}(\mathrm{HMMD})_{t}{ }^{-}$ $0.210 *{ }^{2} I B O R_{t}$

$L O G(I H K)_{t}=3.189-0.005 * P P J K_{t}+0.031 * S U B S_{t}+$

$0.165 *$ BIRATE $_{t}-0.413 *$ LOG $(\text { IHEKS })_{t^{-}}$

$0.104 * \operatorname{LOG}(\text { IMPDN })_{t}-0.075 *{ }^{*} O G(\text { IHIMP })_{t}+$

$0.329 * \operatorname{LOG}(\mathrm{M} 1)_{t}-1.782 *{ }^{*} \mathrm{LOG}(\mathrm{IHKD})_{t}+$ $0.286 * \operatorname{LOG}(\mathrm{HMMD})_{t}-0.052 * \mathrm{LIBOR}_{t}$

$L O G(K B L N)_{t}=-12.144+0,027 * P P J K_{t}+0.010 * S_{U B S}+$

$0.105 *$ BIRATE $_{t}-0.070 * L O G(\text { IHEKS })_{t}-$

$0.160 * \operatorname{LOG}(\text { IMPDN })_{t}+1.245 * \operatorname{LOG}(\text { IHIMP })_{t}+$ $1.644 * \operatorname{LOG}(\mathrm{M1})_{t}-0.315 * \operatorname{LOG}(\mathrm{IHKD})_{t}-$ $0.137 * \operatorname{LOG}(\mathrm{HMMD})_{t}-0.083 * \mathrm{LIBOR}_{t}$

$L O G(P D B E)_{t}=0.011+0.106 * P P J K_{t}+0.724 * S U B S_{t}-$

$0.184 * B_{\text {IRATE }}-0.665 *$ LOG $(\text { IHEKS })_{t}+$

$0.128 * \operatorname{LOG}(\text { IMPDN })_{t}+1.779 *$ LOG(IHIMP) $)_{t}$ $+0.608 * \operatorname{LOG}(\mathrm{M} 1)_{t}-0.195 * \operatorname{LOG}(\mathrm{IHKD})_{t}+$ $0.140 * \operatorname{LOG}(\mathrm{HMMD})_{t}+0.005 * \mathrm{LIBOR}_{t}$ 


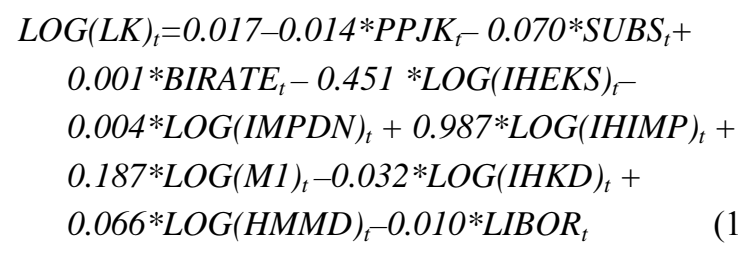

The results of residual normality test committed against structural equations, obtained the error term normally distributed. Based on the value of the probability distribution of the error term with a $95 \%$ confidence level, the results show that each equation unless exchange rates and prices, residual is normally distributed. Autocorrelation test results indicate the occurrence of autocorrelation on exchange rate equation, is an indication of the implementation of the operations of the market and the stability of exchange rates of foreign currency against domestic conducted by the monetary authority. On the other hand, the problem of heteroscedasticity is resolved by giving a check mark on a menu heteroscedasticity consistent covariance and white. The results of testing performed on the entire parameters equation being estimated, no multicollinearity symptoms.

In line with the basic theory Keyness, in the short-term as well as long results estimation model of consumption shows positive influence disposable income of consumption. The estimation results show autonomous consumption, has a positive and significant value in accordance with the theory. The small size of the potential response of consumption caused by people's lives is still low and grappling on the fulfillment of basic needs. The research is in line with the Rahutami (2007) that the results of the estimation of the monetary block pointed out that in the short term the number of real money supply is influenced positively by the real national income and interest rates. Monetary policy rules became the focus of control of inflation gives interesting results. The interest rates and the money supply are the variables that affect inflation with strong influence in the long run. The interaction between fiscal and monetary block seen relationship of causality. When the interest rate shock to see that Government spending provides a significant influence, a surprise primary money will also provide a significant influence on the ac- ceptance of the Government. The following equation is derived i.e. goods market equilibrium model IS, or money market equations model LM and equation of balance of payments model known as a BOP.

\section{The Goods Market Equilibrium (IS Model)}

The IS model is the goods market equilibrium curve that describes the relationship between the real Gross Domestic Product in the nominal interest rate. The equation for market goods are as follows:

$$
\begin{aligned}
& L O G(P D B E)=0,412+0,538 * L O G(P D B E- \\
& \text { t-stat } 5,664 * * * \quad 2,561 * * \\
& \text { PPJK+SUBS) }-0,012 * L O G(\text { BIRATE })+ \\
& -1,256 \\
& +0,2003 * L O G((K U R S * I H E K S) / I H K)- \\
& 1,219 \\
& \text { 0,197*LOG (KURS*IHIMP)/IHK+ } \\
& -1,368 \\
& 0,397 *(K O N S+I N V+K O N P)- \\
& 1,980 * * \\
& 0,018 * \operatorname{LOG}(\text { KONP }) \\
& 0,955
\end{aligned}
$$

$R$-squared $=0.997 \quad D W=1.420$

$L O G(Y)_{t}=\frac{1}{1-0,404+0,059}\left(9,302-0,046 * \operatorname{LOG}(i)_{t}\right)$

IS derivative model as follow:

$\operatorname{LOG}(Y)_{t}=14,201-0,070 * \operatorname{LOG}(i)_{t}$

This equation shows that GDP (aggregate income) is the sum of expenditure on consumption (KONS) which is influenced by Disposable Income, the investment is influenced by the level of world interest rates that have a negative relationship, the government spending, and net exports are affected by exchange rates.

From the above equation it is determined that the coefficient multiplier (multiplier) C, I, G and $\mathrm{X}$ are:

$\frac{1}{1-c+m}=\frac{1}{1-0.238+0.002}=\frac{1}{0.764}=1.308$

And the coefficient multiplier for $\mathrm{M}$ is:

$\frac{-\beta_{1}}{1-c+m}=\frac{-0,012}{1-0.238+0.397}=\frac{-0.014}{1.159}=-0.010$ 
Coefficient multiplier of the real sector in the goods market by 1.308 is a positive impact injection into the national economy. The changes increased the value of the variable in the real sector, such as consumption, investment, government spending and exports will impact 1.308 fold increase the GDP. A number of import 0.010 multipliers give a negative impact, leakage against the value of GDP. After getting the equation of supply and demand money, then money market balance can be obtained, namely LM model. LM curve is a function that shows the relationship between GDP at a variety of possible interest rate (BIRATE), eligible money market balance. Terms of the balance of the money market is the correct fulfillment of the similarity between the demand for money by offering money. The equation for the balance of the money market is as follows:

$$
\begin{aligned}
& L O G(M 2)=2.322+0.178 * L O G(P D B E)- \\
& \text { t-stat } 3.583^{* * *} \quad 1.248 \\
& 0.137 * \text { LOG(BIRATE)-0.137*LOG(IHK)+ } \\
& -2.208 * * \quad-1.378 \\
& +0,763 K B L N \\
& 5.929 * * * \\
& R \text {-squared }=0.894 \quad D W=0.126 \\
& \operatorname{LOG}(Y)_{t}=\frac{1}{0,162}\left(4,277+0,028 * \operatorname{LOG}(i)_{t}\right)
\end{aligned}
$$

LM derivative model as follow:

$$
\operatorname{LOG}(Y)_{t}=26,401+0,173 * \operatorname{LOG}(i)_{t}
$$

Quotes from real money balance will be equal to the number of requests. Real money balance is associated with positive GDP. Equation of the money supply is the amount of the money supply (M2), which is the central bank's monetary policy, while the demand for money is the liquidity of the economy. Based on equation 16, it appears that if interest rates fall by $1 \%$ (one basis point), the gross domestic product will increase by $0.137 \%$ and when the gross domestic product increased by $1 \%$ due to the condition of the money market equilibrium interest rate has increased by $1.37 \%$, equivalent to 0.0137 basis points.

\section{Fiscal Policy Multiplier}

Fiscal policy Multiplier indicates how much of the increase in government spending can change the rate of gross domestic production of equilibrium with the assumption that monetary policy is constant. The fiscal policy multiplier (MKF) in Indonesia as follows:

$$
\begin{aligned}
\mathrm{MKF} & =\frac{-0,028 * 1.527}{-0.028+(0.162 *-0.046 * 1.527)}=\frac{-0.042}{-0.039} \\
& =1.077
\end{aligned}
$$

These results provide interpretations that enhanced government spending amounted to one trillion dollars without any monetary policy will result in additional gross domestic product amounted to 1.077 times of large government spending or reach one trillion seventy-seven billion dollars. Small numbers of the fiscal multiplier are suspected because of a very open system in the Indonesia's economy and the system of free exchange rates. The system on the marginal value of profess propensity to import is big enough, eventually affecting the fiscal multiplier value to be small.

\section{Monetary Policy Multiplier}

The next step is specified the number of multipliers monetary policy that is projecting GDP. The test is performed against the operation of monetary policy without any fiscal policy can be derived as follows:

$$
\begin{aligned}
\text { MKM } & =\frac{-0.046 * 1.527}{-0.028+(0.162 *-0,046 * 1.527)}=\frac{-0.070}{-0.039} \\
& =1.795
\end{aligned}
$$

The calculation result of monetary policy multipliers number gained mention that monetary policy actions through increased money supply amounted to one trillion rupiah would result in additional GDP of 1.795 of the magnitude of the amount of additional money, in circulation or reach one billion seven hundred ninety-five billion rupiah. In relation to monetary policy, the integration of the world's financial system has led to the use of monetary quantity (monetary aggregates) are increasingly less reliable as a target for controlling inflation. Rapid growth of monetary aggregates is often 
considered a reflection of the occurrence of financial deepening rather than as a threat of inflation. Therefore, the use of inflation targeting framework (ITF) adopted by a growing number of developing countries because they realize that the appropriate monetary policy requires monetary authorities to have a clear commitment to the achievement of low inflation.

\section{The Effectiveness of Fiscal Policy and Monetary Policy}

Multiplier monetary policy greater than fiscal policy multiplier in the economy of Indonesia, then monetary policy is believed to be more effective in affecting an increase in GDP. The addition of the same expenditure in monetary policy will add to GDP amounted to 1.795 times the value changes while fiscal policy will add to GDP amounted to 1.077 times the value change, assuming the other variables fixed. Monetary policy effective when people use the money in accordance with the functions of money in the economy. The strong relationship between the core money (M1) on the supply of money (monetary policy) as well as the higher level of monetarization in society, the more effective monetary policy in an economy.

Results of the research in Indonesia during the period 1970 to 2005 indicates monetary policy more effective in influencing fiscal policy rather than an increase in national income. Indonesian economy as the economic picture that is closer to the characteristics of a small open economy model of the economy, monetary policy is a response of the international economic turmoil. Through the Mundell-Fleming theory approach, monetary policy conducted by Bank Indonesia did not viewable to transmission, through changes in interest rates that will fundamentally affect investment. Bank Indonesia monetary policy conducted by the main variable is the interest rate and the exchange rate through the transmission of perfect capital flows (fixed capital mobility) on the Indonesian economy. Changes in exchange rates will affect the relative price of Indonesian commodities in foreign markets that ultimately affect aggregate expenditure (GDP) through increased exports. Indonesia's export value can be captured through the role of imported commodities, such as raw materials in the industry that increased imports of industrial raw materials might lead to national exports.

In the application of research results, should be implemented with caution because such policies can not stand on its own. Indonesia's fiscal multiplier tends to be low for the need to look for factors that lead to it. According to Hemming (2002), theoretically fiscal multipliers will continue to be positive and may be further increased if (1) there is overcapacity in the economy so additional government spending will boost demand for goods / services and an increase in demand for goods and services can be met; (2) The increase in government spending is not a substitute for private spending that will accelerate the productivity of labor and capital, as well as lower taxes increase investment and labor supply; (3) Fiscal policy still needs to be balanced with monetary expansion policy by taking into account the increase in controlled inflation.

Research on the effectiveness of fiscal policy and monetary policy in other countries get the monetary policy more effective. Barro (1991), using a variety of models with different combinations of variables and simple regression analysis with data cross section as well as the observations of 98 countries over the period 19601985, stated that the Government consumption expenditure (fiscal policy) has a negative influence to the economic growth and investment growth. Ramayandi (2009) studies suggest that monetary policy in five ASEAN countries (Indonesia, Malaysia, Singapore, Thailand and the Philippines) have been running efficiently. In line with research Ramayandi (2009), the results of the study Tang et al. (2010) about the impact of changes in fiscal policy in five ASEAN countries, namely Indonesia, Thailand, Singapore, the Philippines and Malaysia showed that the fiscal multiplier impact due to the shock from taxes and Government spending is very small. The result of the impulse response of GDP to government spending in the five countries is close to zero and statistically insignificant. 
Formal stability test performed on individual equations, simultaneous equations while the test is done indirectly. The test results indicate that the stability of individual equation model of investment and private consumption model is less satisfactory according to the test criteria CUSUM and CUSUM of squares as shown in Table 5 below.

\section{Sensitivity Analysis}

Sensitivity testing is carried out using the results of structural equations that have been tested previously. Variables that are given the shock is an instrument of economic policy, namely, fiscal policy by giving a shock on a tax receipt. The magnitude of the shocks supplied in lightweight scale policy changes amounted to ten percent (10) and fifty percent (50) for both the combination of policies that are contractive as well as expansive. The magnitude of the shock given to test the pessimistic economic policy simulations and optimistic, in addition to the basic model in forecasting (baseline). The model testing was conducted on a one-quarter in 2000 up to four.

The reason for the election period is in line with the enactment of Law No. 23/1999 on Bank Indonesia. Based on the law, Bank Indonesia carryout a policy to achieve the inflation targets and must be announced to the public. Since the year 2000 Bank Indonesia basically has begun to implement a monetary policy framework known as Inflation Targeting Framework. This simulation is carried out to the range $1997 \mathrm{q} 3$ to $2011 \mathrm{q} 4$ which represents a system of flexible exchange rate system, a decision that enforced the Government since August 14, 1997.

Table 5. CUSUM Stability Test and CUSUM of SQUARES

\begin{tabular}{|c|c|c|c|c|c|}
\hline \multirow{2}{*}{ No. } & \multirow{2}{*}{ Equation } & \multicolumn{2}{|c|}{ CUSUM } & \multicolumn{2}{|c|}{ CUSUM OF SQUARES } \\
\hline & & Short-term & Long-term & Short-term & Long-term \\
\hline 1. & Private Consumption & Stable & Unstable & Unstable & Stable \\
\hline 2. & Investment & Unstable & Unstable & Unstable & Stable \\
\hline 3. & Government Consump. & Stable & Stable & Stable & Unstable \\
\hline 4. & Export & Stable & Stable & Stable & Stable \\
\hline 5. & Import & Stable & Stable & Stable & Stable \\
\hline 6. & Money Supply & Stable & Unstable & Stable & Stable \\
\hline 7. & Exchange Rate & Stable & Stable & Unstable & Stable \\
\hline 8. & Price & Stable & Stable & Stable & Stable \\
\hline 9. & Net Asset Abroad & Stable & Stable & Stable & Stable \\
\hline 10. & GDP & Stable & Stable & Stable & Stable \\
\hline 11. & Employment & Stable & Stable & Unstable & Stable \\
\hline
\end{tabular}

KELN

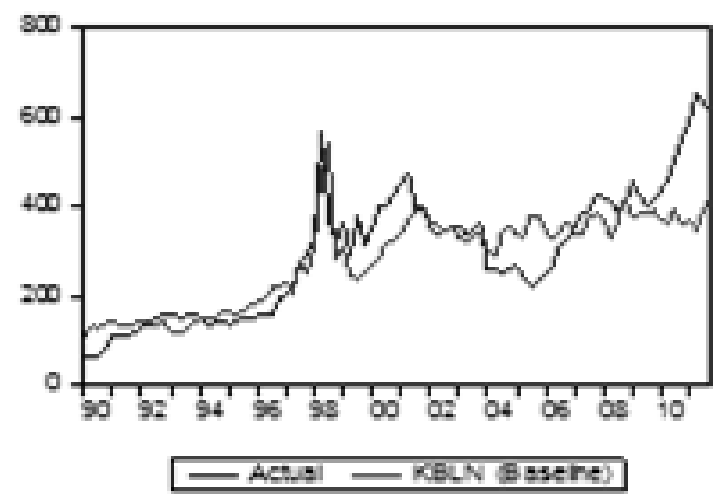

KONP

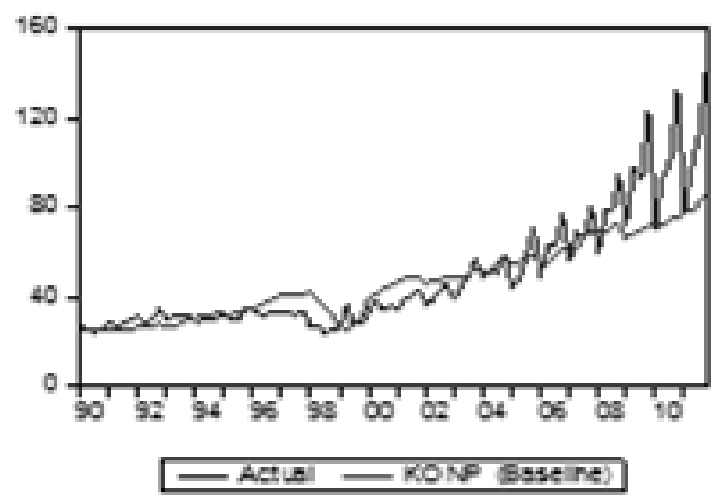

Figure 1.a The values predicted from baseline model against actual data (net foreign wealth and government consumption) 
WN

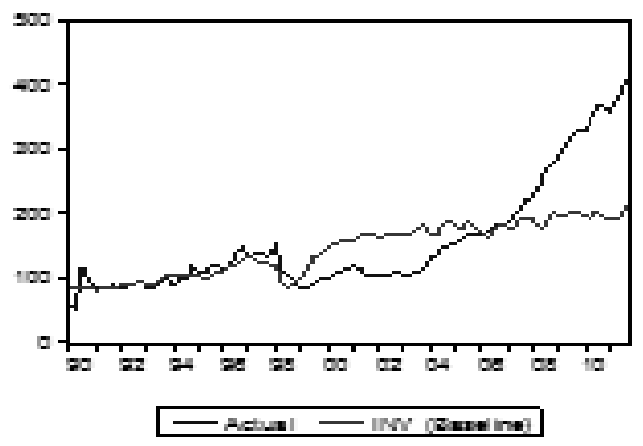

$\sqcup K$

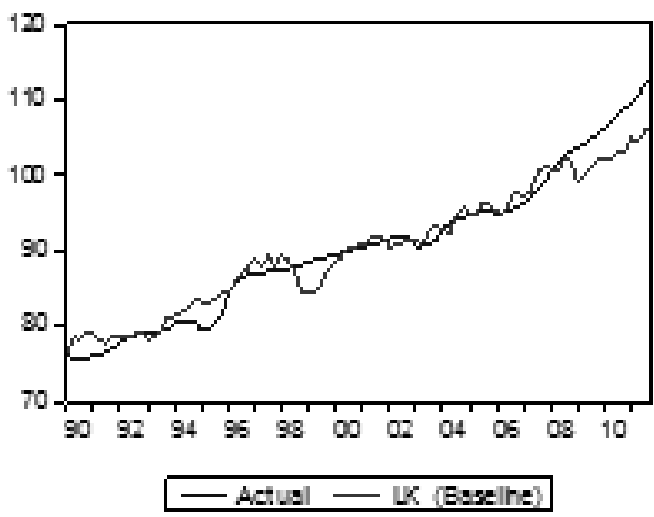

EKSP

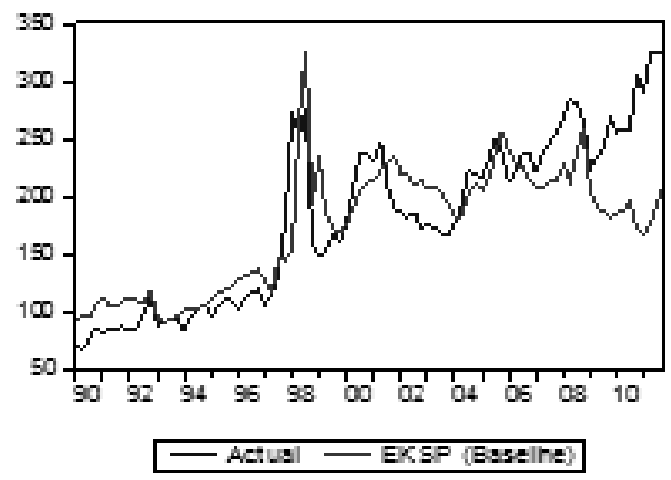

KONS

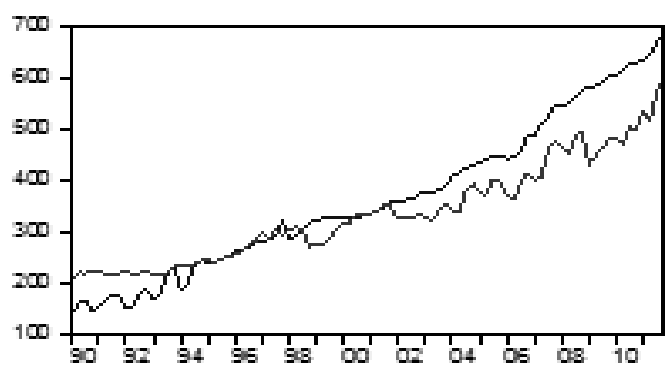

- Actual - KONS (Bsseine)
KuFs

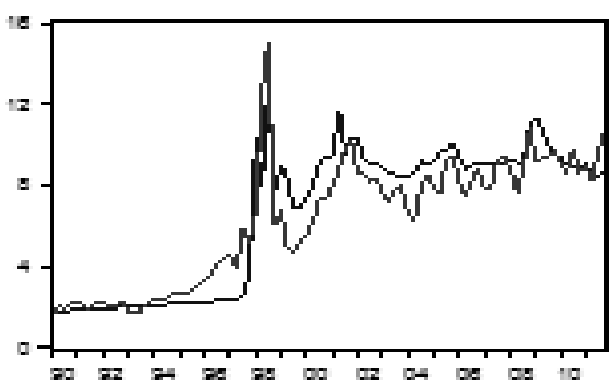

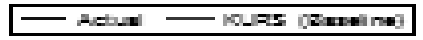

M2

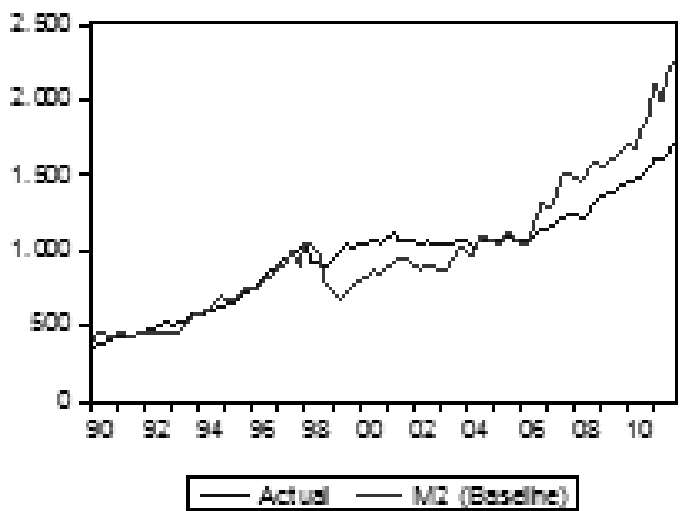

IHK

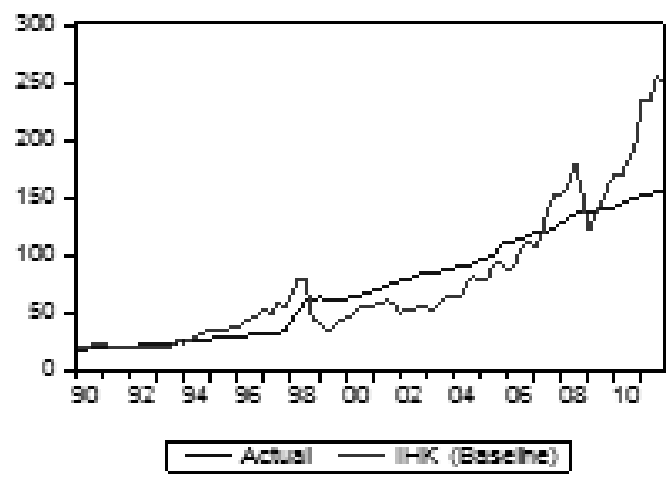

IMPR

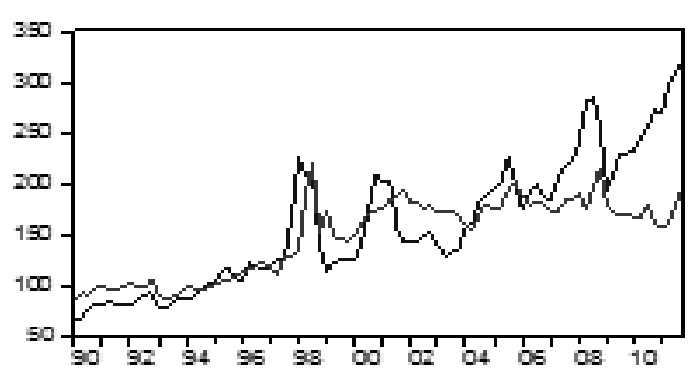

- ACtual - IMPR Bsseine?

Figure 1b. The values predicted from baseline model against actual data (investment, exchange rate, employment, money supply, export, consumer price index, private consumption and import) 


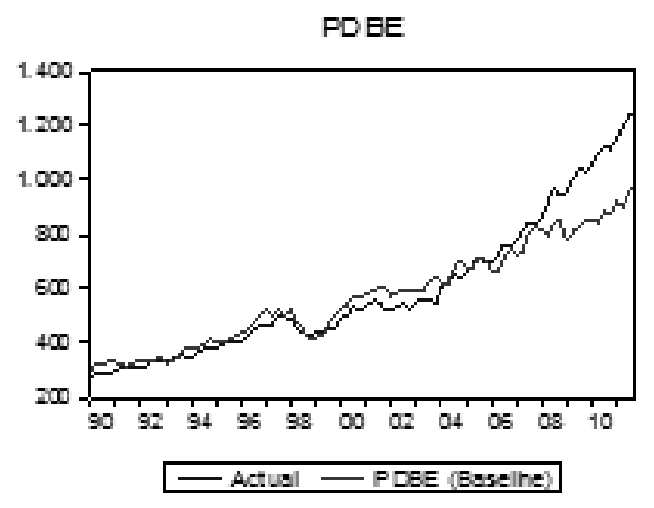

Source: output eviews6

Figure 1c. The values predicted from baseline model against actual data (gross domestic product expenditure)

On the structure of simultaneous equations are obtained, simulations performed with the basic model to predict the accuracy of the GDP model with Gauss-Seidall solver and deterministic solving static nature. As shown in Figure $1 \mathrm{a}, 1 \mathrm{~b}$ and $1 \mathrm{c}$, that model has a pretty good fitting between the actual data with the model essentially on all variables. In the graph indicates that the behavior of the resulting predictive data on each variable base model has a pattern that follows the actual data. The result shows that the model can be used to perform policy simulations.

In particular, this research aims to analyze the impact of fiscal and monetary policy to changes in GDP. The simulation is carried out by taking into account three elements, namely: the shock of capital outflow, changes in economic policy and economic policy changes at a time when capital flows out. Economic development scenarios carried out basic model with thirteen types of shock. Simulations performed with various scenarios, expansionary fiscal economic policy, contractionary fiscal and monetary expansionary and contractionary monetary. Forecasting with the model when compared with the actual data in 2012 and the basic model, it was found that the trend follows the pattern of the actual data.

Fiscal policy through tax policies provide the stimulus to GDP contraction, monetary policy influences the market via interest rates would affect aggregate demand. Economic policy is expansionary contractions and is expected to make a direct impact to GDP. The policy mix within the framework of the goods market equilibrium (IS), the money market (LM) and balance of payments (BOP) consider the role of coordination for each acting independently. The success of macro-economic policies, such as fiscal policy, monetary, trade and industry in achieving the end goal can not stand on its own. Policy without regard to policies in other sectors will not be optimal and even can negatively impact the overall economy. Overly expansionary fiscal policy as the above may encourage the onset of inflation, so that fiscal policy is too tight like a high tax rate increase in community consumption may decrease or reduce the allocation of productive fund so that it could suppress economic growth.

The results are consistent with research Santoso (2012), that most of the fiscal and monetary policy mix in Indonesia period 1984-2010 is contractionary monetary policy with contractionary fiscal policy (complement) and contractionary monetary policy with an expansionary fiscal policy (substitution). Expansionary fiscal policy is done through an increase in the fiscal balance to GDP ratio compared to the previous year. Using the monetary policy instrument nominal interest rates compared with the interest rates of the previous period. There are several reasons why monetary and fiscal policies should be coordinated within the framework of price stability and growth. Firstly, the limitation of the instrument to achieved the target. These limita- 
tions can be derived from a consideration of the impact of the instrument on which the target can be distinguished for the short term and long term. Secondly, to maintain the stability of output and inflation, in order not to deteriorate as a result of the lack of coordination between monetary and fiscal policy. Coordination of monetary and fiscal policy can provide a clear separation of the two policies on the basis of the structure of the grace period policy. Third, the importance of coordination between monetary and fiscal policy is the difference in perception between the two authorities, what is the best for the nation. Simulation conducted by giving shocks through three variables, namely interest rates, taxation and conditions of entry of foreign capital outflows to see the direction of the interaction of fiscal and monetary policy. Indonesia are characterized as small open economies, in using Mundell Fleming model the economy is assumed with the current mobility incoming foreign capital came out perfectly. The enactment of Law No. 23/1999 concerning the independence of Bank Indonesia, the choice of exchange rate policy is a freely floating exchange system, a consequence of the model of the impossible trinity. Indonesia has changed the policy of free floating exchange rate system since August 14, 1997 (third quarter). For each fiscal and monetary policy, the price level in this equation will determine the level of disposable income and the exchange rate that balances the goods market and the money market.

\section{CONCLUSION}

Based on empirical facts, the interaction of monetary and fiscal policy are causality. Interest rates and money are the two primary variables that got more attention from Bank Indonesia because it interacts strongly with the Government budget. Indonesia's economy during the past 20 years, i.e. during the period of research suggests that the monetary policy is more effective than fiscal policy affect the increase in GDP. Obtaining monetary policy multiplier greater than fiscal policy multiplier, also be affirmed through a quantity level slope of the curve model
IS a very elastic while the level of the slope of the curve model LM is less elastic.

Based on the results of the simulation is clear that the economy of Indonesia is highly vulnerable to the impact of capital flow out. Due to the high dependence on foreign capital flows, the event of rapid capital outflows large quantities, national economic conditions rapidly deteriorated. In normal conditions and in the event of a crisis happening, this research proves that the combination of macro policy that gives the best results is an expansive fiscal policy to offset by contractionary monetary policy. To achieve the interaction of monetary and fiscal policy, the optimal interest rate volatility or variants need to be maintained intensively as minimum as possible relative to GDP variants.

\section{Implication}

Fiscal policy multiplier tends to be low in Indonesia, it was necessary to look for factors that lead to it. Based on the results of testing the model, there is excess capacity in the economy so as to increase government spending will drive increased demand for goods and services. In practice, each authority should determine the policy momentum to best exit points that produce a more optimal impact. The Government can play a role in increasing government spending to encourage increased output given that Government consumption theoretically is a direct role in the formation of GDP. The implication of this condition is the behavior of the fiscal sector is a sign that still need to be in the response by BI as a monetary authority. Fiscal policy expansionary on floating exchange rate regime will shift the balance of market goods (IS) to the right, resulting in a strengthened exchange rate and GDP are relatively fixed. The change occurred in the balance of the money market (LM) are vertical, implies a flow of incoming foreign capital exit. The level of interest rates and the exchange rate becomes the primary variable, while domestic interest rates are higher than the interest rate international, result in the inflow of foreign capital until the rupiah strengthens. Finally, the net exports will decline the impact of fiscal policy expansionary to lower 
GDP. On the monetary policy side of the increase in the money supply affect domestic interest rates in order not to fall below the level of international interest that resulted in outflows of foreign capital.

\section{The Limitation of the Research}

The limitations in this research especially in Mundell-Fleming model, which has not entered any element of expectation that is quite affecting the dynamics of macroeconomic variables. There is a possibility of changing the effectiveness between fiscal policy and monetary policy from time to time. Further research is required for each respective period by including a dummy variable in order to find out the possibility of changes in the effectiveness of monetary and fiscal policy from time to time.

To measure the impact of economic policy changes or assignment of welfare, recommended barometer is the equivalent variation (EV) or compensating variation (CV). In this context, EV measures the amount of income needed (sacrificed) by consumers (community) to receive a new level of prosperity as a result of policies that are applied, while $\mathrm{CV}$ measures how much must be paid by the consumer to maintain their initial level of well-being.

\section{REFERENCES}

Arif, Al, M. Maulana dan Achmad Tohari, 2006. "Peranan Kebijakan Moneter Dalam Menjaga Stabilitas Perekonomian Indonesia Sebagai Respon Terhadap Fluktuasi Perekonomian Dunia" [The Role of Monetary Policy In Indonesia Economic Stability Keeping In Response to the World Economic Fluctuations]. Buletin Ekonomi Moneter dan Perbankan, 9(2), 145 - 177.

Barro, Robert. J., 1991. "Economic Growth in Cross Section Countries". Quaterly Journal of Economics, 106 (2), 407-443.

Blanchard, Olivier, Giovanni Dell'Ariccia, and Paolo Mauro, 2010. "Rethinking Macroeconomic Policy". Journal of Money, Credit, and Banking, 42 (Supplement), 199-215.
Blanchard, Oliver, Giovanni Dell'Ariccia and Paolo Mauro, 2013. "Rethinking Macro Policy II: Getting Granular". IMF Staff Discussion Note SDN/13/03.

Blanchard, O., and R. Perotti, 2002. "An Empirical Characterization of Dynamic Effects of Changes in Goverment Spending and Taxes on Output". Quartely Journal of Economics, 117, 139-168.

Christiansen, L, 2008. "Fiscal Multipliers-A Review of the Literature". Appendix II to IMF Staff Position Note 08/01, Fiscal Policy for the Crisis, Washington: International Monetary Fund.

Chuku, Chuku A, 2009. "Measuring the Effects of Monetary Policy Innovations in Nigeria: A Structural Vector Autoregressive (SVAR) Approach". African Journal of Accounting, Economics, Finance and Banking Research, 5 (5).

Freedman, C., M. Kumhof, D. Laxton and J. Lee, 2009. "The Case for Global Fiscal Stimulus". IMF Staff Position Note 09/03, Washington: International Monetary Fund.

Ganev, G., Molnár, K., Rybiński, K. and Woźniak, P., 2002. "Transmission Mechanism of Monetary Policy in Central and Eastern Europe". CASE Reports No. 52.

Giavazzi, F. And M. Pagano, 1990. "Can Severe Fiscal contractions be Expansionary? Tales of Two Small European Countries". NBER Macroeconomics Annual 1990, Cambridge, Massachusetts, National Bureau on Economic Research, 75-122.

Gujarati, Damodar N, 2003. Basic Econometric. International Edition by McGraw-Hill Education (Asia) Printed in Singapore, ISBN: 0-07-233542-4.

Hemming, R., M. Kell and S. Mahfouz, 2002. "The Effectiveness of Fiscal Policy in Strimulating Economic Activity - A Review of the Literature". IMF Working Paper 02/208, Washington: International Monetary Fund.

Hsieh, Wen-Jen, 2009. "Study of the Behavior of the Indonesian Rupiah/US Dollar 
Exchange Rate and Policy Implications". International Journal of Applied Economics, 6(2), $41-50$.

Joseph, Charles PR, et.al., 1999. "Kondisi dan Respon Kebijakan Ekonomi Makro Selama Krisis Ekonomi Tahun 1997-98" [Conditions and Macroeconomic Policy Response During Economic Crisis Year 1997-98]. Buletin Ekonomi Moneter dan Perbankan, 2(2), 97-129.

Konuki, T., 2000. "The Effect of Monetary Policy on Agregat Demand in Small Open Economy”. IMF Working Paper

Leitemo, K., 2004. "A Game between the Fiscal Policy and the Monetary Authorities Under Inflation Targerting". European Journal of Political Economy 2 20, 709-724.

Maryatmo, R., 2004. "Dampak Moneter Kebijakan Defisit Anggaran Pemerintah dan Peranan Asa Nalar Dalam Simulasi Model Makro-Ekonomi Indonesia (1983:1-2002: 4)" [Impact of Monetary of Government Budget Deficit Policy and the Role of Rational Expectation In Indonesia MacroEconomic Model Simulations (1983: 12002: 4)]. Bulletin Ekonomi Moneter dan Perbankan, 7(2), 297-322.

Mochtar, Firman, 2004. "Fiscal and Monetary Policy Interaction: Evidences and Implication for Inflation Targeting in Indonesia". Bulletin Ekonomi Moneter dan Perbankan, 7(3), 359-386.

Ortiz, Javier and Carlos Rodriguez, 2002. "Country Risk And The Mundell-Flemming Model Applied to the 1999-2000 Argentine Experience". Journal of Applied Economics, $\mathrm{V}(2), 327-348$.

Perotti, R., 2005. "Estimating the Effects of Fiscal Policy in OECD Countries", CEPR Discussion Paper, No. 4842, London: Centre for Economic Policy Research.

Rahutami, Angelina Ika, 2007. "Interaksi Kebijakan Moneter dan Fiskal: Dominasi atau Kausalitas?" [Interaction of Monetary and Fiscal Policy: Domination or Causality?]. Koordinasi dan Interaksi Kebijakan Fiskal-
Moneter: Tantangan ke Depan. Kanisius, 171-191.

Ramayandi, Arif, 2009. “Assessing Monetary Policy Efficiency in the ASEAN-5 Countries". Working Paper in Economics and Development Studies No. 200902, Center for Economics and Development Studies (CEDS) Padjadjaran University.

Romer, C., and D. Romer, 2008. "The Macroeconomic Effects of Tax Changes: Estimates based on a New Measure of Fiscal Shocks". Unpublished Manuscript: University of California at Berkeley.

Santoso, Wijoyo, 2012. "Interaksi Kebijakan Moneter dan Fiskal di Indonesia" [Interaction of Monetary and Fiscal Policy in Indonesia]. Koordinasi dan Interaksi Kebijakan Fiskal-Moneter: Tantangan ke Depan. Kanisius, 225-262.

Simorangkir, Iskandar, 2007. "Koordinasi Kebijakan Moneter Dan Fiskal Di Indonesia: Suatu Kajian Dengan Pendekatan Game Theory" [Monetary and Fiscal Policy Coordination in Indonesia: A Review With Game Theory Approach]. Buletin Ekonomi Moneter dan Perbankan, 9 (3), 5-30.

Simorangkir, Iskandar and Justina Adamanti. 2010. "Peran Stimulus Fiskal dan Pelonggaran Moneter Pada Perekonomian Indonesia Selama Krisis Finansial Global: Dengan Pendekatan Financial Computable General Equilibrium" [The Role of Fiscal Stimulus and Monetary Easing On the Indonesian Economy During the Global Financial Crisis: The Financial Computable General Equilibrium Approach ]. Buletin Ekonomi Moneter dan Perbankan, 13 (2), 169 - 192.

Siregar, H., \& Ward, D.B, 2000. "Can Monetary Policy Shocks Stabilise Indonesian MacroEconomy Fluctuations?". Paper presented at the 25th Annual Conference of the Federation of ASEAN Economis Associations in Singapore on $7-8$ September 2000.

Solikin, 2005. "Analisis Kebijakan Moneter Dalam Model Makroekonometrik Struktural Jangka Panjang" [Analysis of Monetary 
Policy in the Long Term Structural Macroeconometric Model]. Buletin Ekonomi Moneter dan Perbankan, 8(2), 191 - 229.

Tang, Hsiao Chink, Philip Liu and Eddie C. Chung, 2010. "Changing Impact of Fiscal Policy on Selected ASEAN Countries". $A D B$ Working Paper Series on Regional Economic Integration, No. 70 December 2010 Asian Development Bank.

Yoshino, N., 1998. Presentation Material at UREM, Unpublished.

Yunanto, M. and Henny Medyawati, 2011. "Studi Mengenai Pembatasan Arus Mobilitas Modal dan Nilai Tukar (Kurs): Kajian Literatur" [Study of Flow Restriction of Capital Mobility and Exchange: Literature Review]. Prosiding Seminar Ilmiah Nasion- al PESAT LPUG. 18-19 Oktober 2011, E.80-E85.

Yunanto, Muhammad, 2013. "Dampak Kebijakan Fiskal dan Moneter Terhadap Produk Domestik Bruto (PDB) Indonesia: Tahun 1990-2011" [The Impact of Fiscal and Monetary Policy Against Gross Domestic Product (GDP) of Indonesia: in the Period 1990-2011]. Unpublished Dissertation. Post Graduate Programme. Universitas Gunadarma, Jakarta.

Yunanto, M and Henny Medyawati, 2013. "Macroeconomic Strutural Change in Indonesia: in the Period of 1990-2011". International Journal of Trade, Economics and Finance, 4(3), 98-103. 